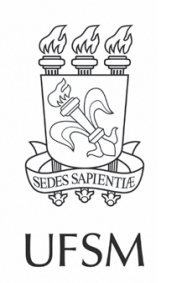

\title{
Artigos
}

\section{Floristic and structure of different strata in an urban Semideciduous Forest in Jataí, Goiás state, Brazil}

\author{
Florística e estrutura de diferentes estratos em uma Floresta Estacional \\ Semidecidual urbana, Jataí, GO
}

\section{Frederico Augusto Guimarães Guilherme $1{ }^{\oplus}$, Wendy Carniello Ferreira $1{ }^{\bullet}$, Gabriel Eliseu Silva ${ }^{1}$, , Deivid Lopes Machado ${ }^{1}$}

' Universidade Federal Jataí, Jataí, GO, Brazil

\begin{abstract}
Comparative studies between different strata of forests in ecological succession are important to understand the forest dynamics. The study evaluated floristic, phytosociological and ecological aspects between the tree and regenerating strata of an urban fragment of semideciduous forest, in Jataí, Goiás state. In the last decades, the vegetation that was typically savanna has become a forest. Trees (diameter at breast height, $\mathrm{DBH} \geq 5 \mathrm{~cm}$ ) were sampled in 12 permanent $200 \mathrm{~m}^{2}$ plots. In each of them, $25 \mathrm{~m}^{2}$ subplots were sampled for the regenerant stratum, which comprised individuals with $\mathrm{DBH}<5 \mathrm{~cm}$ and height $\geq 1 \mathrm{~m}$. Regenerants had greater richness (31 species), with two more species than adults. There was low floristic and structural similarity between the strata, indicating a replacement of species over time. Shannon's diversity was significantly lower for the tree stratum ( $t$ test), since it presented low equability, with ecological dominance of few species. Both strata had a high proportion of pioneer species, when compared to other studies. Zoochory and species of forest environments were significantly more abundant in the regenerating stratum. The study revealed a fragment in a frank process of secondary succession and vulnerability in the face of anthropic pressures, with care regarding its conservation being important.
\end{abstract}

Keywords: Ecological succession; Floristic and structural similarity; Natural regeneration; Dispersal mechanisms 


\section{RESUMO}

Estudos comparativos entre diferentes estratos de florestas em sucessão ecológica são importantes para entender a dinâmica florestal. O estudo avaliou aspectos florísticos, fitossociológicos e ecológicos entre os estratos adulto e regenerante de um fragmento urbano de floresta estacional semidecidual, em Jataí, Goiás. Nas últimas décadas, a vegetação que era tipicamente savânica tem se tornado uma floresta. As árvores adultas (diâmetro a altura do peito, DAP $\geq 5 \mathrm{~cm}$ ) foram amostradas em 12 parcelas permanentes de $200 \mathrm{~m}^{2}$. Em cada uma delas, sub-parcelas de $25 \mathrm{~m}^{2}$ foram amostradas para o estrato regenerante, que compreendeu indivíduos com DAP $<5 \mathrm{~cm}$ e altura $\geq 1 \mathrm{~m}$. Regenerantes tiveram maior riqueza (31 espécies), com duas espécies a mais do que os adultos. Houve baixa similaridade florística e estrutural entre os estratos, indicando uma substituição de espécies ao longo do tempo. A diversidade de Shannon foi significativamente menor para o estrato arbóreo (teste $t$ ), visto que apresentou baixa equabilidade, com dominância ecológica de poucas espécies. Ambos os estratos tiveram elevada proporção de espécies pioneiras, quando comparado com outros estudos. Zoocoria e espécies de ambientes florestais foram expressivamente mais abundantes no estrato regenerante. 0 estudo revelou um fragmento em franco processo de sucessão secundária e vulnerabilidade diante de pressões antrópicas, sendo importante os cuidados quanto à sua conservação.

Palavras-chave: Sucessão ecológica; Similaridade florística e estrutural; Regeneração natural; Mecanismos de dispersão

\section{INTRODUCTION}

Urban forests are recognized as all native forest vegetation within or around cities, considered fundamental elements of the green infrastructure of urban perimeters (SALBITANO et al., 2016; BRUN et al., 2017). However, are subject to constant anthropic pressure. These forests improve human well-being, as they regulate microclimate conditions, mitigate air and noise pollution, function as recreation, socialization and environmental education places (CARREIRO et al., 2008). In addition, they contribute with the species richness and diversity, and with ecosystem services of natural environments. Therefore, knowing the ecological aspects of urban forest fragments can provide subsidies for the management, conservation and ecological restoration actions at the local level. Since species are subject to constant disturbances and their dynamics may change over time (CARREIRO et al., 2008).

Secondary succession in forest formations has been well investigated in the Neotropics, although studies on ecological aspects in urban forests are still scarce 
(PAIVA; RIBEIRO; CARVALHO, 2015). This generates information gaps exactly in the areas that demand the greatest need for environmental services for human wellbeing, limiting the subsidy of the aforementioned actions. In this sense, assessing the vegetation of urban forests, through the study of different strata, is an effective alternative. In particular the regenerating strata, since they encompass a layer of ephemeral plants, are more vulnerable to disturbances, which modify the microclimate conditions of a forest environment. Therefore, investigating the processes involved in natural regeneration is essential, with a focus on understanding the likely floristic and structural changes in forest ecosystems (CALLEGARO et al., 2015; SANTANA; FONSECA; CARVALHO, 2019).

Comparative assessments between different stages of tree development in forests provide important information about the community dynamics (OLIVEIRA; FELFILI; SILVA JÚNIOR, 2015). They can also contribute as indicators of the conservation status of natural environments in process of ecological succession, with wide relevance in agricultural expansion regions. Some studies have been carried out under this perspective, in ecosystems with different physiognomies and disturbance histories, and in the most varied regions of Brazil (MOREIRA; FONSECA; CARVALHO, 2013; AMARAL et al., 2015; AGUIAR et al., 2017). Nevertheless, in Goiás state, studies like this are still incipient (MILHOMEM; ARAÚJO; VALE, 2013) and specifically in the southwestern of Goiás, only the work of Ferreira et al. (2018), who studied natural regeneration in an urban gallery forest in the Jataí city, but without a comparative purpose.

This meso-region of the state, that reflects land use and occupation, underwent an accelerated deforestation process with the spread of agricultural activity, followed by the expansion of urban centers. Studies show that around 1980, the region still had approximately half of its native vegetation cover, and currently not more than $30 \%$ (MARTINS et al., 2016). In this sense, the objective of this study was to compare the floristic composition, structure, diversity and ecological aspects of the tree and the regenerating strata in an urban semideciduous forest fragment. 
Several studies, point out that open Cerrado physiognomies, when protected from fire, shows stages of succession, advancing from savanna to forest physiognomies (ABREU et al., 2017; SILVA et al., 2019). In this sense, we work with the following hypotheses: 1 . due to the secondary succession stage, the urban forest show differences in composition and floristic similarity, structure and ecological aspects between tree and regenerating strata; 2. after 40 years of conservation, we hope to find a higher proportion of species and individuals in the initial succession stage than normally registered in other studies and, still, a higher proportion of species typical of forest environments.

\section{MATERIAL AND METHODS}

\subsection{Study site}

The study was conducted at the Samuel Graham Ecological Park (SGEP) owned by the Samuel Graham Presbyterian Institute, in the urban perimeter of the Jataí city, Goiás state $\left(17^{\circ} 52^{\prime} 48^{\prime \prime} S ; 5^{\circ} 43^{\prime} 38^{\prime \prime} \mathrm{W}\right)$. SGEP has concrete trails along its entire length and is open to the public, offering space for leisure and walks. The Park has about 3.5 hectares, find on a red Oxisol with a clay texture and flat relief, at an approximate altitude of $770 \mathrm{~m}$. The climate of Jataí is classified as Aw, according to Köppen (ALVARES et al., 2013), with seasonality marked by drought in winter and rain in summer. The annual average rainfall is approximately $1650 \mathrm{~mm}$, with rainfall occurring mainly between the months of October and April. In the rainy season, the humidity is always greater than $70 \%$, with higher average temperatures. In the dry period, the average temperature approaches $18^{\circ} \mathrm{C}$, in which the relative humidity does not exceed $50 \%$, with extremes occurring in June and July (GUILHERME et al., 2011).

Satellite images, photographic collections and reports from ancient inhabitants date back to 40 years ago, show that SGEP was practically devoid of woody vegetation. Composed an altered savanna vegetation, with sparse tree typical of cerrado sensu 
stricto, and the herbaceous layer was dominated by exotic grasses, especially Urochloa spp. Along with the enclosure and absence of fire records in recent decades, the park had a gradual thickening. Thus, the area has been transformed into a forested environment, in a notorious succession process. Currently, secondary semideciduous forest vegetation predominates, and with various exotic tree, shrub and herbaceous plants.

\subsection{Vegetation survey}

Vegetation sampling was carried out in 2018 and 12-10×20m (200m²) plots of were randomly allocated to survey the tree stratum (hereinafter referred to as the tree stratum). In each plot, we allocate a $5 \times 5 m\left(25 \mathrm{~m}^{2}\right)$ sub-plot to survey the regenerating stratum. The total sample encompass 0.24 and 0.04 hectares for both strata, respectively.

Within the plots and sub-plots, we account and identify all individuals of tree species, which diameter and height were measured. Individuals with diameter at breast height $(\mathrm{DBH}) \geq 5 \mathrm{~cm}$, and with $\mathrm{DBH}<5 \mathrm{~cm}$ and height $(H) \geq 1 \mathrm{~m}$, were considered as tree and regenerating stratum, respectively. Some specimens not recognized in the field, had botanical material collected, aiming at identification through consulting the literature and comparisons with the Herbário Jataiense $(\mathrm{HJ})$ voucher collections of the Federal University of Jataí. The species were grouped into families recognized by the Angiosperm Phylogeny Group (2016).

\subsection{Ecological attributes}

For the analysis of the plant community structure, the relative phytosociological parameters of density (DR) and frequency (FR) were used. Shannon's diversity $\left(H^{\prime}\right)$ and Pielou's equability $\left(J^{\prime}\right)$ indices were also calculated. We classify the species according to their origin: 1. native: species of natural occurrence in Goiás state or Cerrado; 2. exotic: non-native species, introduced. For seed dispersal mechanisms, species were 
compared between both strata and arranged in three categories (zoochoric, autochoric and anemochoric), based on field experiences, fruit morphology and species taxonomic knowledge, following criteria proposed by Van Der Pijl (1982).

In order to comparatively evaluate the vegetation response between strata, we classify the species according to the demand for light, in two categories: 1. pioneer: species that colonize altered environments and in an initial stage of succession, typical of more illuminated environments; 2 . secondary: species that do not establish themselves in full light, regenerating and establishing themselves under broad spectrum of luminosity, but in more shady conditions. Species in this group may exhibit different survival and growth responses depending on the region or environment where they are found. Since in the recent past the studied site was a typically non-forest environment and today the forest goes through several stages, with few species of final stages of succession, this criterion for classifying ecological groups was adapted (sensu SWAINE; WHITMORE, 1988), grouping light demanding and shade tolerant species in the secondary category.

In the floristic aspect, for the two strata, species were categorized according to the preference for habitats in: 1. forest: preferred forest formations; 2 . savannas: preferred savannas and 3. generalists: those species with wide distribution throughout Cerrado and also other Brazilian biomes. This classification followed studies on the distribution of woody species (e.g. SOLÓRZANO et al., 2012), and still had field experience, for the species observed in other habitats in southwestern Goiás and surrounding regions.

\subsection{Data analysis}

To verify differences related to the densities of ecological groups, dispersion mechanisms and preference for habitats between strata, we submitted the attributes to the Student's $t$ test (5\%). The diversity index was statistically compared between the two strata, applying the Hutcheson $t$ test (ZAR, 2010). In addition, to compare the floristic and structural similarity between strata, we used the Jaccard and Morisita 
similarity indices, respectively. We perform the calculations in a Microsoft Office Excel 2007® electronic spreadsheet.

We performed a cluster analysis from a similarity matrix based on the BrayCurtis index, which was used to test the possible groupings between the strata. The cluster significance was tested by the Similarity Analysis (CLARKE; WARWICK, 2001). The analyzes were performed with the R software (R DEVELOPMENT CORE TEAM, 2014).

\section{RESULTS AND DISCUSSION}

\subsection{Floristic and structure comparisons}

Throughout the survey, we registered 47 species, belonging to 28 botanical families. For the tree and regeneration strata, we sampled 211 individuals (879 ind. ha $^{-1}$ ), distributed in 29 species, and 79 individuals (1975 ind.ha-1), distributed in 31 species, respectively. The density per hectare of regenerating individuals was more than twice as high as trees, which is usually recorded in comparative studies between strata, including in semideciduous seasonal forests in Goiás (VENTUROLI; FELFILI; FAGG, 2011; MILHOMEM; ARAÚJO; VALE, 2013). This indicates the urban forest selfregenerate capacity.

The families with the largest species number in the whole survey were Fabaceae (8 species), followed by Myrtaceae (5), Anacardiaceae (3) and Moraceae (3). Myrtaceae and especially Fabaceae, in general, have the greatest richness in surveys not only of semideciduous forests (GUILHERME; NAKAJIMA, 2007), but other forest formations in the Brazilian Cerrado (ANDRIANI et al., 2020; FERREIRA et al., 2020; MARTINS et al., 2020).

The diversity index $\left(\mathrm{H}^{\prime}\right)$ of trees and regenerants was 2.44 and 3.11 nats.ind $^{-1}$, respectively, and was significantly higher for the regenerating stratum $(t=3.92 ; p<$ $0.001)$. This reveals a high specific dominance for the tree strata $\left(J^{\prime}=0.73\right)$, evidenced by the lower recorded equability than the regenerating ones $\left(J^{\prime}=0.91\right)$. The diversity 
values are low when compared to other semideciduous forests in the Brazilian Central Plateau, both for adult trees (PEIXOTO et al., 2012; MARTINS et al., 2020), and for immature individuals (VENTUROLI; FELFILI; FAGG, 2011). These data suggest that the forest fragment is still in a secondary succession stage, with little structural complexity and low plant richness and diversity, which is also explained by the density being concentrated in a few species. Only three of the 29 species, Hymenaea martiana, Didymopanax morototoni e Matayba guianensis, encompass $62 \%$ and $41 \%$ of all tree strata density and frequency, respectively (Table 1; Figure 1). This low uniformity, that is, few species predominating in the survey, is an aspect already observed for other tropical forests in the succession process (MOREIRA; FONSECA; CARVALHO, 2013; PAIVA; RIBEIRO; CARVALHO, 2015). Milhomem, Araújo and Vale (2013) also found Didymopanax morototoni as one of the most important in semideciduous forest in southern Goiás. This species dominates the fragment studied by analyzing the vertical structure, covering the canopy of the urban forest, since its individuals had the highest average heights (11.2m), when compared with the other species and also with the total average height of the trees $(9.2 \mathrm{~m})$.

Table 1 - Density of tree (TS) and regenerating (RS) strata, and ecological attributes, in decreasing order of the total individual number $(\mathrm{N})$ in the whole survey in the urban fragment of semideciduous forest, Jataí, Goiás state

\begin{tabular}{lcccccccc}
\hline \multicolumn{1}{c}{ Family } & Species & N & TS & RS & H & EG & DM & OR \\
\hline Fabaceae & Hymenaea martiana Hayne & 55 & 53 & 2 & G & S & Zoo & N \\
Araliaceae & Didymopanax morototoni (Aubl.) Decne \& Planch & 51 & 49 & 2 & $\mathrm{~F}$ & $\mathrm{P}$ & Zoo & $\mathrm{N}$ \\
Sapindaceae & Matayba guianensis Aubl. & 44 & 29 & 15 & $\mathrm{~F}$ & $\mathrm{~S}$ & Zoo & $\mathrm{N}$ \\
Rutaceae & Zanthoxylum rhoifolium Lam. & 17 & 11 & 6 & $\mathrm{G}$ & $\mathrm{P}$ & Zoo & $\mathrm{N}$ \\
Fabaceae & Anadenanthera peregrina (L.) Speg. & 10 & 6 & 4 & $\mathrm{C}$ & $\mathrm{S}$ & Ane & $\mathrm{N}$ \\
Bignoniaceae & Cybistax antisyphilitica (Mart.) Mart. & 8 & 4 & 4 & $\mathrm{C}$ & $\mathrm{S}$ & Ane & $\mathrm{N}$ \\
Fabaceae & Leptolobium dasycarpum Vogel & 8 & 8 & 0 & $\mathrm{C}$ & $\mathrm{S}$ & Ane & $\mathrm{N}$ \\
Anacardiaceae & Tapirira guianensis Aubl. & 7 & 5 & 2 & $\mathrm{~F}$ & $\mathrm{~S}$ & Zoo & $\mathrm{N}$ \\
Bignoniaceae & Jacaranda cuspidifolia Mart. & 7 & 7 & 0 & $\mathrm{~F}$ & $\mathrm{~S}$ & Ane & $\mathrm{N}$ \\
Arecaceae & Syagrus oleraceae (Mart.) Becc. & 6 & 6 & 0 & $\mathrm{G}$ & $\mathrm{S}$ & Zoo & $\mathrm{N}$ \\
Anacardiaceae & Mangifera indica L. & 6 & 5 & 1 & $\mathrm{~F}$ & $\mathrm{~S}$ & Zoo & $\mathrm{E}$ \\
Euphorbiaceae & Mabea fistulifera Mart. & 5 & 1 & 4 & $\mathrm{G}$ & $\mathrm{P}$ & Zoo & $\mathrm{N}$ \\
& & & & & & Continued ...
\end{tabular}


Table 1 - Conclusion

\begin{tabular}{|c|c|c|c|c|c|c|c|c|}
\hline Family & Species & $\mathbf{N}$ & TS & RS & $\mathbf{H}$ & EG & DM & OR \\
\hline Primulaceae & Myrsine umbellata Mart & 5 & 3 & 2 & $\mathrm{~F}$ & $P$ & Zoo & $\mathrm{N}$ \\
\hline Fabaceae & Inga laurina (Sw.) Willd. & 4 & 0 & 4 & $\mathrm{~F}$ & $P$ & Zoo & N \\
\hline Rubiaceae & Guettarda viburnoides Cham. \& Schltdl. & 3 & 0 & 3 & G & $S$ & Zoo & $\mathrm{N}$ \\
\hline Annonaceae & Xylopia aromatica (Lam.) Mart. & 3 & 3 & 0 & G & $S$ & Zoo & $\mathrm{N}$ \\
\hline Urticaceae & Cecropia pachystachya Trécul & 3 & 3 & 0 & G & $P$ & Zoo & $\mathrm{N}$ \\
\hline Moraceae & Maclura tinctoria (L.) D. DonexSteud. & 3 & 1 & 2 & $\mathrm{~F}$ & $S$ & Zoo & N \\
\hline Euphorbiaceae & Sapium glandulosum (L.) Morong & 3 & 0 & 3 & $\mathrm{~F}$ & $P$ & Zoo & N \\
\hline Siparunaceae & Siparuna guianensis Aubl. & 3 & 2 & 1 & $\mathrm{~F}$ & $P$ & Zoo & N \\
\hline Moraceae & Brosimum gaudichaudii Trécul & 3 & 0 & 3 & C & $S$ & Zoo & N \\
\hline Myrtaceae & Myrcia splendens (Sw.) DC. & 3 & 0 & 3 & C & S & Zoo & N \\
\hline Moraceae & Ficus gomelleira Kunth & 2 & 2 & 0 & G & $P$ & Zoo & N \\
\hline Meliaceae & Guarea guidonia (L.) Sleumer & 2 & 0 & 2 & $\mathrm{~F}$ & $S$ & Zoo & N \\
\hline Burseraceae & Protium heptaphyllum (Aubl.) Marchand & 2 & 0 & 2 & $\mathrm{~F}$ & S & Zoo & N \\
\hline Myrtaceae & Syzygium cumini (L.) Skeels & 2 & 0 & 2 & $\mathrm{~F}$ & $S$ & Zoo & $\mathrm{E}$ \\
\hline Fabaceae & Cenostigma pluviosum (DC.) G.P. Lewis & 2 & 2 & 0 & $\mathrm{~F}$ & S & Aut & E \\
\hline Anacardiaceae & Astronium fraxinifolium Schott & 2 & 2 & 0 & $\mathrm{~F}$ & $P$ & Ane & N \\
\hline Salicaceae & Casearia silvestris Sw. & 2 & 0 & 2 & C & S & Zoo & N \\
\hline Dilleniaceae & Curatella americana L. & 2 & 1 & 1 & C & $S$ & Zoo & N \\
\hline Combretaceae & Buchenavia tomentosa Eichler & 1 & 0 & 1 & G & $S$ & Zoo & N \\
\hline Malpighiaceae & Byrsonima sericea DC. & 1 & 0 & 1 & G & S & Zoo & N \\
\hline Myrtaceae & Eugenia uniflora L. & 1 & 0 & 1 & G & $S$ & Zoo & N \\
\hline Myrtaceae & Psidium sp & 1 & 0 & 1 & G & $S$ & Zoo & N \\
\hline Rubiaceae & Genipa americana L. & 1 & 1 & 0 & $\mathrm{~F}$ & $S$ & Zoo & N \\
\hline Chrysobalanaceae & Licania tomentosa (Benth.) Fritsch & 1 & 0 & 1 & $\mathrm{~F}$ & S & Zoo & E \\
\hline Myrtaceae & Plinia cauliflora (Mart.) Kausel & 1 & 0 & 1 & $\mathrm{~F}$ & S & Zoo & $E$ \\
\hline Piperaceae & Piper aduncum L. & 1 & 0 & 1 & $\mathrm{~F}$ & $P$ & Zoo & N \\
\hline Fabaceae & Senegalia polyphylla (DC.) Britton Rose & 1 & 1 & 0 & $\mathrm{~F}$ & $P$ & Aut & N \\
\hline Connaraceae & Connarus suberosus Planch. & 1 & 1 & 0 & C & $S$ & Zoo & N \\
\hline Erythroxylaceae & Erythroxylum suberosum A.St.-Hil. & 1 & 0 & 1 & C & S & Zoo & N \\
\hline Chrysobalanaceae & Licania humilis Cham. \& Schltdl. & 1 & 0 & 1 & C & S & Zoo & N \\
\hline Ochnaceae & Ouratea hexasperma (A.St.-Hil.) Baill. & 1 & 1 & 0 & C & $S$ & Zoo & N \\
\hline Sapotaceae & Pouteria ramiflora (Mart.) Radlk. & 1 & 1 & 0 & C & S & Zoo & N \\
\hline Fabaceae & Dimorphandra mollis Benth. & 1 & 1 & 0 & C & S & Aut & $\mathrm{N}$ \\
\hline Fabaceae & Stryphnodendron polyphyllum Mart. & 1 & 1 & 0 & C & S & Aut & $\mathrm{N}$ \\
\hline Apocynaceae & Aspidosperma macrocarpon Mart. Zucc. & 1 & 1 & 0 & C & $\mathrm{S}$ & Ane & $\mathrm{N}$ \\
\hline
\end{tabular}

Source: Authors (2020)

Where: H: habitat (G: generalist; F: forestry; C: savanna); EG: ecological group (P: pioneer; S: secondary); DM: dispersion mechanism (Zoo: zoochoric; Ane: anemochoric; Aut: autochoric); OR: origin (N: native; E: exotic). 
Figure 1 - Relative values of density and frequency of the 10 main species in number of individuals for each stratum in the urban fragment of semideciduous forest, Jataí, Goiás state

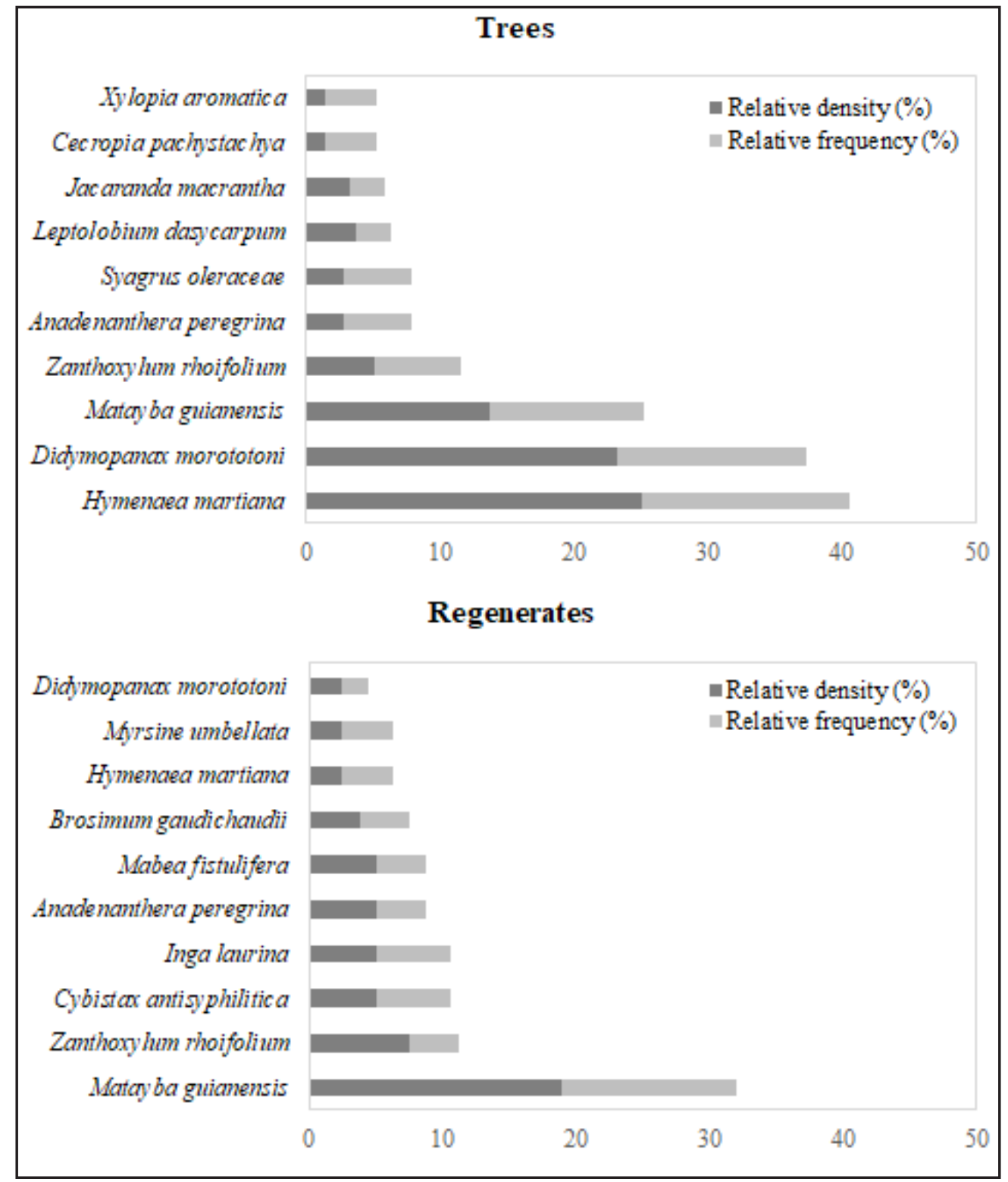

Source: Authors (2020)

Among all 47 species, only 13 were common between both strata, providing high qualitative dissimilarity, in which $72 \%$ were exclusive to each stratum. The floristic and structural similarity values calculated were 0.28 and 0.48 , respectively. This difference in species composition was also found by ANOSIM $(p=0.001)$, with the formation of two 
groups, as observed in the cluster analysis (Figure 2). Therefore, our results indicate an expressive difference in species composition between strata, although some more important in terms of abundance predominate in both, as for example, Matayba guianensis and Zanthoxylon rhoifolium. These two species had the largest number of individuals in the regenerating stratum (Table 1). The results suggest that the forest fragment has been undergoing floristic changes, although structurally we can expect the maintenance of the typical conditions of a seasonal semideciduous forest, if there are no major disturbances, such as fire or severe drought events.

Figure 2 - Cluster analysis of similarity between tree and regenerating strata in the urban fragment of semideciduous forest, Jataí, Goiás state

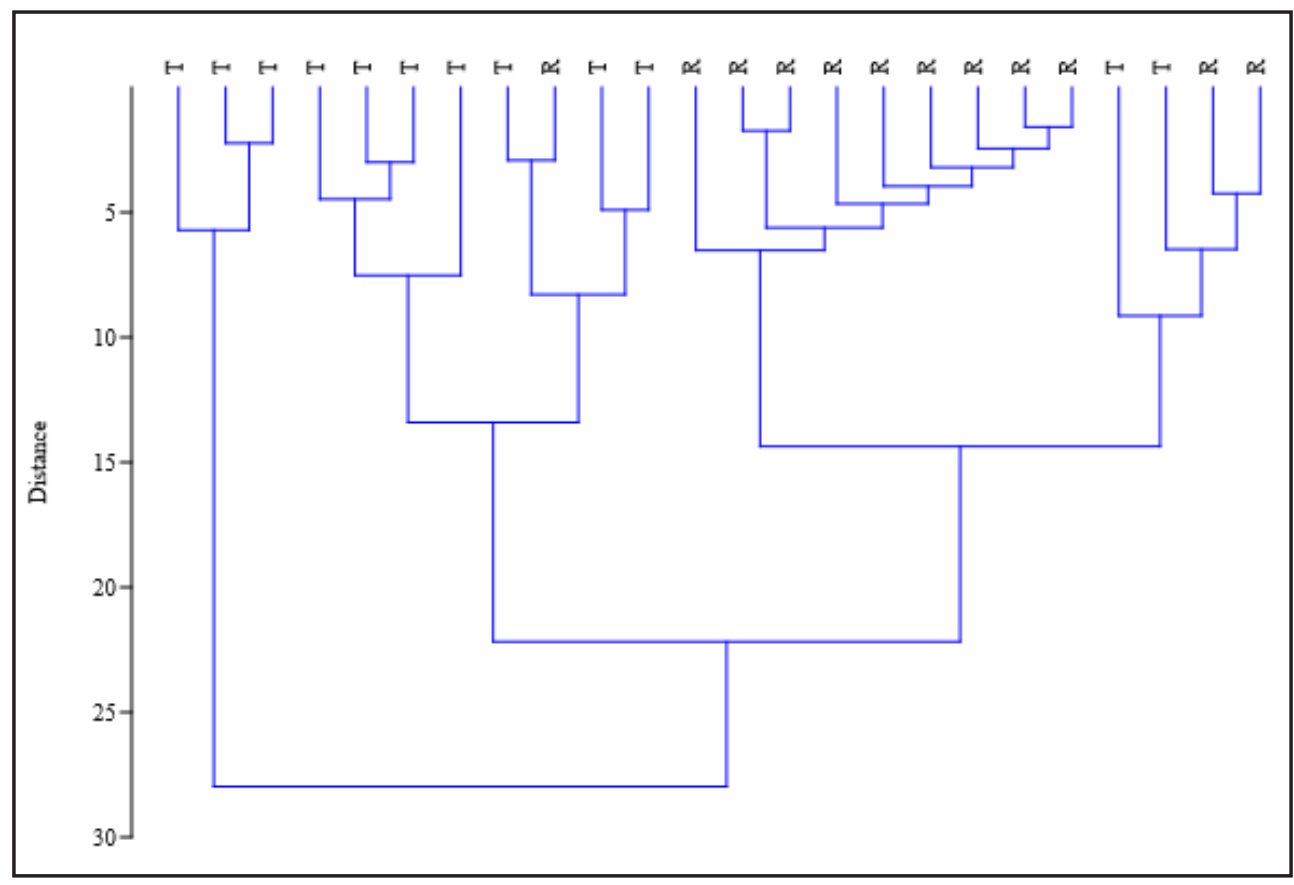

Source: Authors (2020)

Five species that were nonnative to Cerrado were recorded in the survey (Table 1), among which Mangifera indica stood out with six adult plants and one regenerant. Due to this low abundance, neither the mango tree nor any of the four exotic species seem to show signs of accelerated occupation, to the point of compromising the forest dynamics, under the aspect of biological invasion, a concern already reported in other 
studies on semideciduous forests in Brazil (MOREIRA; FONSECA; CARVALHO, 2013; SANTIAGO; FONSECA; CARVALHO, 2014). In these cases, the adequate management is necessary for the control of the invasive species, since, in general, they are notorious competitors and can delay the native species development (SANTANA; FONSECA; CARVALHO, 2019).

\subsection{Ecological attributes}

Regarding the dispersion mechanisms, zoochory was predominant in both strata, with almost $86 \%$ of all individuals and 37 species, while another 10 species are autochoric and anemochoric (Figure 3-A; Table 1). Comparisons between strata indicated differences only for zoochory, with significantly higher density in the regenerating stratum $(t=-3.59 ; p=0.003)$. Our findings corroborate records from other studies in semideciduous forests in the Central Plateau of Brazil (MILHOMEM; ARAÚJO; VALE, 2013). There are records that zoochory is also dominant in natural regeneration in places under ecological restoration processes (COLMANETTI et al., 2016). In general, the occurrence of zoochoric species is important in natural ecosystems, since it increases the environmental complexity, with more interactions between animal and plant species. Even more notable is the predominance of zoochory in environments isolated by anthropic matrices, as in the case of the studied forest, which is surrounded by homes and undergoes constant urban pressures. Thus, the presence of zoochoric species in the fragment and the consequent supply of fruits for the fauna, indicates that there is a flow of animals, especially the avifauna. These urban forests can serve as nesting and refuge sites for wild fauna of Cerrado, especially in the dry period, when the supply of fleshy fruits tends to reduce markedly (PILON; UDULUTCH; DURIGAN, 2015). Therefore, the occurrence of these frugivores allows natural regeneration and consequent maintenance of the forest environment over time, with the constant arrival of diaspores.

For ecological groups, both strata had a great proportion of secondary 
species, with $67 \%$ of the total density, and a significantly higher individuals number in the regenerating stratum $(t=-2.79 ; \mathrm{p}=0.017$; Figure $3-\mathrm{B})$. However, $25 \%$ of the registered species were categorized as pioneers, encompassing approximately 33\% of all individuals in the survey. These values are higher than that registered in other studies in semideciduous forests, both for tree and regenerating plants (DIAS NETO et al., 2009; PRADO JÚNIOR et al., 2012; MILHOMEM; ARAÚJO; VALE, 2013). In general, these studies report proportions between $8-13 \%$ of species richness and $5-19 \%$ of density of pioneer plants in the reproductive stage. Our results again suggest that the studied forest is in a secondary succession stage, which agree with the typical patterns of secondary forests in fragmented and isolated landscapes (PAIVA; RIBEIRO; CARVALHO, 2015). Pioneer species show greater capacity for dispersion and plasticity to overcome adverse environmental conditions, since they are typical of the initial stages of succession and important for the functioning of a forest ecosystem. Thus, they provide favorable conditions for the establishment of other plant species typical of more shaded environments.

For both strata, there was an expressive species number with a preference for forest environments (20 species), while those preferred by savanna or generalist formations covered 15 and 12 species, respectively (Table 1). Considering the density of the whole survey, there was also a predominance of individuals classified as preferred by forest formations, with $51 \%$ of the total number of individuals, in which the regenerating stratum had significantly higher density $(t=-3.67 ; p=0.003$; Figure 3-C). However, this proportion for the group with preference for savanna was only $15 \%$, while the habitat generalists group was $34 \%$. The density of regenerants was also higher for species with preference for savanna environments $(t=-2.42 ; p$ $=0.030)$, whereas we do not find differences between strata for generalist species. The protection against burns and the consequent structuring of the forest canopy, reducing the light incidence, seems to reflect this low abundance of individuals typical of savanna formations in the regenerating stratum. Our data reinforce the succession 
process again and, over time, the environment has ceased to have a savanna condition, starting to present notoriously forestry features. The protection against fires and the consequent structuring of the forest canopy, reducing the incidence of light, seems to reflect this low abundance of individuals typical of savanna formations in the regenerating stratum. In addition, Oxisols also allow forest succession, when free from burning. Therefore, the studied urban forest still undergoes physiognomic alteration, characterized by this patchwork of floristic elements from both savannas and forests, and by the other aspects already discussed. This has also been verified for woody savannas in the Central Plateau of Brazil (SOLÓRZANO et al., 2012; GUILHERME et al., 2020).

Figure 3 - Density of tree and regenerating strata in relation to the dispersion mechanism (A), ecological group (B) and preference for habitats (C) in the urban fragment of semideciduous forest, Jataí, Goiás state

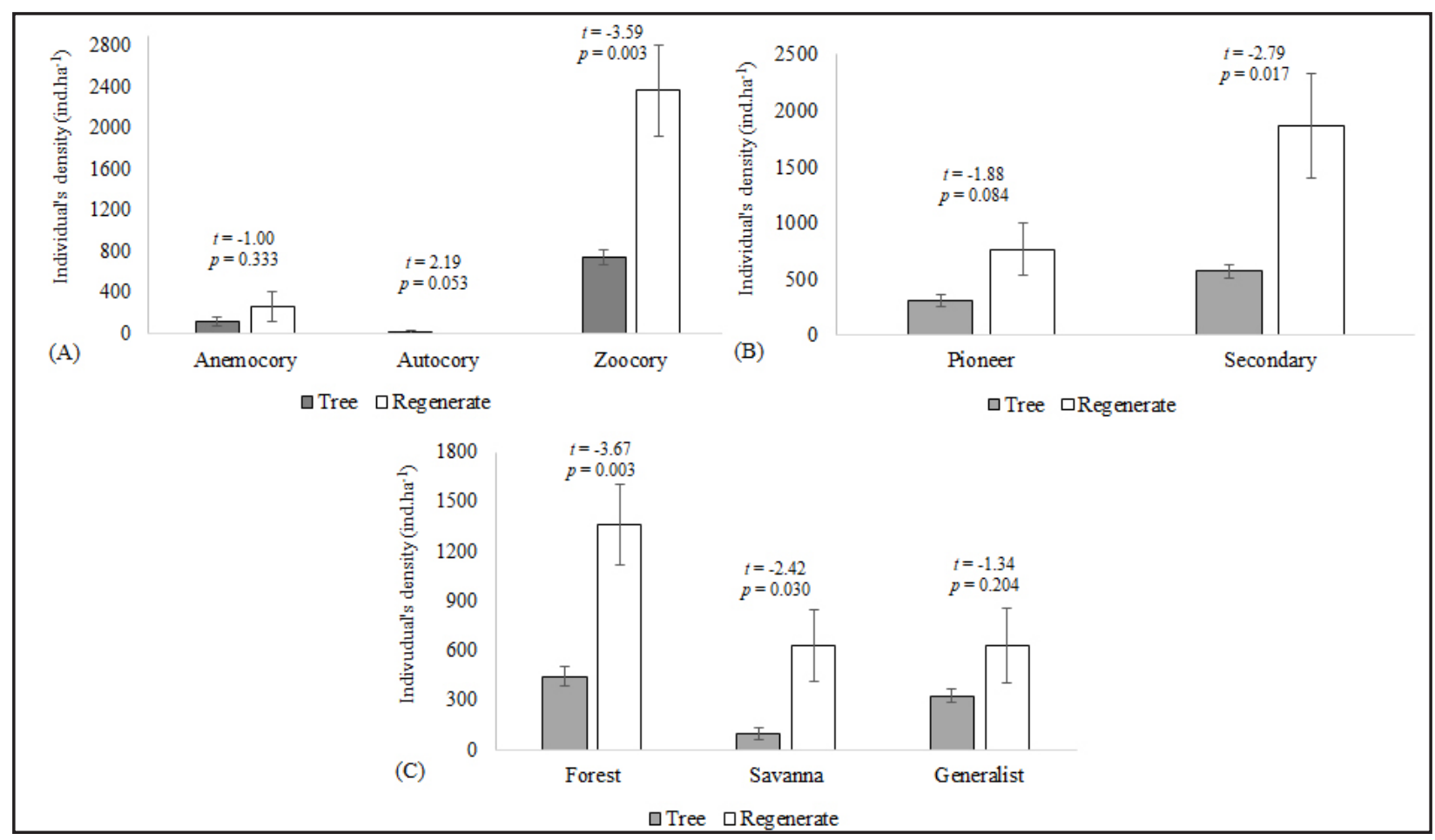

Source: Authors (2020) 


\section{CONCLUSIONS}

In summary, the fragment of urban forest studied showed low diversity due to the dominance of a small set of species, which may indicate some difficulty in the arrival of new species, even with the notorious predominance of the zoochory, mainly in regenerant stratum. The high floristic and structural dissimilarity between the strata indicates that along the succession, species substitution has been occurring in the community. Secondary species and those with preference for forest environments predominated in the regenerant, corroborating our hypothesis. However, proportionally, there was remarkable occurrence of pioneer plants when compared to other studies, which clearly shows the stage of secondary succession, but it also stems from the fact that it is a forest immersed in an urban matrix and of small dimensions. Therefore, an environment vulnerable to disturbances and alterations caused by anthropic actions. However, the urban forest SGEP has ecological and social functions important to the Jataí city, and its preservation is necessary, both by the population and by the public authorities.

\section{Acknowledgment}

To the FAPEG financial support under the PELD-Jataí project (process number 2017/10267000329). To Mr. Izaltino Guimarães (Tininho) for the information and historic images of the study area.

\section{REFERENCES}

ABREU, R. C. R. et al. The biodiversity cost of carbon sequestration in tropical savanna. Science Advances, [s. I.], v. 3, p. e1701284, 2017.

ALVARES, C. A. et al. Köppen's climate classification map for Brazil. Meteorologische Zeitschrift, Berlin, v. 22, p. 711-728, 2013.

AGUIAR, M. D. et al. Similaridade entre adultos e regenerantes do componente arbóreo em floresta com araucária. Floresta e Ambiente, Seropédica, v. 24, p. e00083214, 2017. 
AMARAL, C. S. et al. Comparação florístico-estrutural dos estratos adultos e regenerantes em área minerada de campo rupestre, Diamantina, MG. Cerne, Lavras, v. 21, n. 2, p. 183-190, 2015.

ANDRIANI, M. S. et al. Fitossociologia da vegetação arbórea em ecótono de floresta estacional decidual-cerrado rupestre, Jandaia, GO. Enciclopédia Biosfera, [s. I.], v. 17, n. 33, p. 257-270, 2020.

ANGIOSPERM PHYLOGENY GROUP IV. An update of the Angiosperm Phylogeny Group classification for the orders and families of flowering plants. Botanical Journal of the Linnean Society, London, v. 181, p. 1-20, 2016.

BRUN, F. G. K. et al. Vegetação arbórea em remanescentes florestais urbanos: Bosque do Lago da Paz, Dois Vizinhos, PR. Pesquisa Florestal Brasileira, Colombo, v. 37, n. 92, p. 503-512, 2017.

CALLEGARO, R. M. et al. Regeneração natural de espécies arbóreas em diferentes comunidades de um remanescente de floresta ombrófila mista. Ciência Rural, Santa Maria, v. 45, n. 10, p. 1795-1801, 2015.

CARREIRO, M. M. et al. Ecology, planning and management of urban forests: international perspective. [S. I.]: Springer, 2008. $467 \mathrm{p}$.

CLARKE, K. R.; WARWICK, R. M. Change in marine communities: an approach to statistical analysis and interpretation. Plymouth: Plymouth Marine Laboratory, 2001.

COLMANETTI, M. A. A. et al. Phytosociology and structural characterization of woody regeneration from a reforestation with native species in southeastern Brazil. Revista Árvore, Viçosa, MG, v. 40, n. 2, p. 209-218, 2016.

DIAS NETO, O. C. et al. Estrutura fitossociológica e grupos ecológicos em fragmento de floresta estacional semidecidual, Uberaba, MG. Rodriguésia, Rio de Janeiro, v. 60, n. 4, p. 1087-1100, 2009.

FERREIRA, G. L. et al. Estrutura e distribuição de espécies arbóreas ao longo de um gradiente edáfico em floresta ciliar no sul goiano. Revista do Instituto Florestal, São Paulo, v. 32, n. 1, p. 43-56, 2020.

FERREIRA, W. C. et al. Regeneração natural em uma área de nascentes em recuperação no Parque Ecológico Diacuí, Goiás. Global Science and Technology, [s. I.], v. 11, n. 3, p. 135-146, 2018.

GUILHERME, F. A. G. et al. Fenologia de Cybistax antisyphilitica (Mart.) Mart. ex DC. (Bignoniaceae) na região urbana de Jataí, Goiás. Bioscience Journal, Uberlândia, v. 27, n. 1, p. 138-147, 2011.

GUILHERME, F. A. G.; NAKAJIMA, J. N. Estrutura da vegetação arbórea de um remanescente ecotonal urbano floresta-savana no Parque do Sabiá, Uberlândia, MG. Revista Árvore, Viçosa, MG, v. 31, n. 2, p. 329-338, 2007.

GUILHERME, F. A. G. et al. Estrutura arbórea em um cerradão no sul do estado de Goiás. Enciclopédia Biosfera, [s. I.], v. 17, n. 32, p. 318-328, 2020. 
MARTINS, T. O. et al. Vegetational and edaphic attributes in forest formations in the Cerrado biome. Floresta, Curitiba, v. 50, n. 1, p. 961-970, 2020.

MARTINS, A. P. et al. Uso da terra e cobertura vegetal de 1985 a 2015 no Sudoeste de Goiás e relações com o meio físico. In: PEIXINHO, D. M.; SOUSA, M. S. Reconfiguração do Cerrado: usos, conflitos e impactos ambientais. Jataí: [s. n], 2016. p. 11-34.

MILHOMEM, M. E. V.; ARAÚJO, G. M.; VALE, V. S. Estrutura do estrato arbóreo e regenerativo de um fragmento de floresta estacional semidecidual em Itumbiara, GO. Ciência Florestal, Santa Maria, v. 23, n. 4, p. 679-690, 2013.

MOREIRA, B., FONSECA, S. N.; CARVALHO, F. A. Regeneração natural e relações ecológicas com o estrato arbóreo em um fragmento urbano de Floresta Atlântica. Revista de Biologia Neotropical, Goiânia, v. 10, n. 1, p. 21-27, 2013.

OLIVEIRA, M. C.; FELFILI, J. M.; SILVA JÚNIOR, M. C. Comparação florístico-estrutural dos estratos adulto e de regeneração em mata de galeria perturbada no Distrito Federal. Revista Brasileira de Biociências, Porto Alegre, v. 13, n. 3, p. 142-154, 2015.

PAIVA, R. V. E; RIBEIRO, J. H. C.; CARVALHO, F. A. Estrutura, diversidade e heterogeneidade do estrato regenerante em um fragmento florestal urbano após 10 anos de sucessão florestal. Floresta, Curitiba, v. 45, n. 3, p. 535-544, 2015.

PEIXOTO, K. S. et al. Dinâmica da comunidade arbórea em uma floresta estacional semidecidual sob queimadas recorrentes. Acta Botanica Brasilica, Porto Alegre, v. 26, n. 3, p. 697-708, 2012.

PILON, N. A. L.; UDULUTCH, R. G.; DURIGAN, G. Padrões fenológicos de 111 espécies de Cerrado em condições de cultivo. Hoehnea, São Paulo, v. 42, n. 3, p. 425-443, 2015.

PRADO JÚNIOR, J. A. et al. Fitossociologia, caracterização sucessional e síndromes de dispersão da comunidade arbórea de remanescente urbano de floresta estacional semidecidual em Monte Carmelo, MG. Rodriguésia, Rio de Janeiro, v. 63, n. 3, p. 489-499, 2012.

R DEVELOPMENT CORE TEAM. R: a language and environment for statistical computing. Vienna: R Foundation for Statistical Computing, 2014.

SALBITANO, F. et al. Guidelines on urban and peri-urban forestry. Rome: Food and Agriculture Organization, 2016. 158 p.

SANTANA, L. D.; FONSECA, C. R.; CARVALHO, F. A. Aspectos ecológicos das espécies regenerantes de uma floresta urbana com 150 anos de sucessão florestal: o risco das espécies exóticas. Ciência Florestal, Santa Maria, v. 29, n. 1, p. 1-13, 2019.

SANTIAGO, D. S.; FONSECA, C. R.; CARVALHO, F. A. Fitossociologia da regeneração natural de um fragmento urbano de floresta estacional semidecidual (Juiz de Fora, MG). Revista Brasileira de Ciências Agrárias, [s. I.], v. 9, n. 1, p. 117-123, 2014.

SILVA, G. E. et al. Heterogeneidade ambiental e estrutura da vegetação arbustivo-arbórea em três áreas de cerrado sentido restrito no sudoeste goiano. Ciência Florestal, Santa Maria, v. 29, n. 2, p. 924-940, 2019. DOI: 10.5902/1980509823788 
SOLÓRZANO, A. et al. Perfil florístico e estrutural do componente lenhoso em seis áreas de cerradão ao longo do bioma Cerrado. Acta Botanica Brasilica, Porto Alegre, v. 26, n. 2, p. 328-341, 2012.

SWAINE, M. D.; WHITMORE, T. C. On the definition of ecological groups in tropical rainforest. Vegetatio, [s. I.], v. 75, p. 81-86, 1988.

VAN DER PIJL, L. Principles of dispersal in higher plants. 3th ed. New York: Springer Verlag, $1982,402 \mathrm{p}$.

VENTUROLI, F.; FELFILI, J. M.; FAGG. C. W. Avaliação temporal da regeneração natural em uma floresta estacional semidecídua secundária, em Pirenópolis, Goiás. Revista Árvore, Viçosa, MG, v. 35, n. 3, p. 473-483, 2011.

ZAR, J. H. Biostatistical analysis. New Jersey: Pearson Prentice-Hall, 2010. 944 p.

\section{Authorship Contribution}

\section{1 - Frederico Augusto Guimarães Guilherme}

Biologist, Dr., Professor

https://orcid.org/0000-0002-5623-4127•fredericoagg@ufg.br

Contribution: Conceptualization, Formal Analysis, Funding acquisition, Investigation, Methodology, Project administration, Supervision, Visualization, Writing - original draft, Writing - review \& editing

\section{2 - Wendy Carniello Ferreira}

Agronomist, Dr., Professor

https://orcid.org/0000-0002-0068-5084•wendy@ufg.br

Contribution: Conceptualization, Methodology, Supervision, Visualization, Writing original draft

\section{3 - Gabriel Eliseu Silva}

Biologist, MSc.

https://orcid.org/0000-0002-9472-5242•gabriel_ufg@hotmail.com

Contribution: Methodology, Visualization, Writing - original draft 


\section{4 - Deivid Lopes Machado}

Forestry Engineer, Dr., Professor

https://orcid.org/0000-0002-0567-4288•deivid.machado@ufg.br

Contribution: Formal Analysis, Methodology, Supervision, Visualization, Writing original draft, Writing - review \& editing

\section{How to quote this article}

Guilherme, F. A. G.; Ferreira, W. C.; Silva, G. E.; Machado, D. L. Floristic and structure of different strata in an urban Semideciduous Forest in Jataí, Goiás state, Brazil. Ciência Florestal, Santa Maria, v. 31, n. 1, p. 456-474, 2021. DOI 10.5902/1980509847868. Available from: https://doi. org/10.5902/1980509847868. Accessed: xx abbreviated month 202x. 